\title{
Critical Thinking and Effective Personality in the Framework of Education for Sustainable Development
}

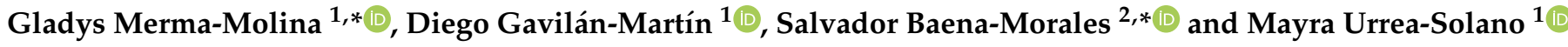 \\ 1 GIDU-EDUTIC/IN Research Group, Department of General and Specific Didactics, Faculty of Education, \\ University of Alicante, 03690 San Vicente del Raspeig, Spain; diego.gavilan@ua.es (D.G.-M.); \\ mayra.urrea@ua.es (M.U.-S.) \\ 2 EDUCAPHYS Research Group, Department of General and Specific Didactics, Faculty of Education, \\ University of Alicante, 03690 San Vicente del Raspeig, Spain \\ * Correspondence: gladys.merma@ua.es (G.M.-M.); salvador.baena@ua.es (S.B.-M.)
}

Citation: Merma-Molina, G.; Gavilán-Martín, D.; Baena-Morales, S.; Urrea-Solano, M. Critical Thinking and Effective Personality in the Framework of Education for Sustainable Development. Educ. Sci. 2022, 12, 28. https://doi.org/ 10.3390/educsci12010028

Academic Editors: Michele Biasutti, Dunja Anđić, Nena Rončević and Nena Vukelić

Received: 4 October 2021

Accepted: 29 December 2021

Published: 5 January 2022

Publisher's Note: MDPI stays neutral with regard to jurisdictional claims in published maps and institutional affiliations.

Copyright: (C) 2022 by the authors. Licensee MDPI, Basel, Switzerland. This article is an open access article distributed under the terms and conditions of the Creative Commons Attribution (CC BY) license (https:// creativecommons.org/licenses/by/ $4.0 /)$.

\begin{abstract}
According to UNESCO, critical thinking (CT) is a strategic skill for the 21st century, as it is associated with attitudes of personal and social change and improvement. Based on this, the objectives of this study were (1) to find out the possible relationships between CT and effective personality (EP) and (2) to determine the extent to which EP predicts the development of CT in children and adolescents. The research approach was quantitative, correlational and predictive. The sample consisted of 562 Spanish students. The measurement instruments were: (1) the Critical Thinking Disposition Inventory and (2) the Efficacy Personality Questionnaire. The main findings showed that there is a positive relationship between EP and CT, with the traits "being enthusiastic", "developing positive self-esteem" and "having self-confidence" correlating most strongly with CT. The regression analysis shows that EP influences the development of students' CT. There were no significant differences according to sex, and Primary Education students obtained higher CT scores. It is concluded that the better the promotion of EP, the greater the CT development will be. This suggests the need to design educational programmes for the improvement of EP, especially in adolescents.
\end{abstract}

Keywords: education for sustainable development; self-esteem; critical thinking; personal traits; school

\section{Introduction}

UNESCO [1] states that the fundamental mission of Education for Sustainable Development (ESD) is to develop students' capacity to make informed decisions and take actions that contribute to building a just society for present and future generations. In this sense, ESD aims to enable present generations to meet their needs while providing the opportunity for future generations to meet theirs. In recent years, this definition has been broadened to a more inclusive and ambitious conception aimed at improving the lives of all people [2]. Therefore, UNESCO [3,4] defines ESD as lifelong learning, and underlines the transformative potential of this educational approach, as it enables people to acquire the competences needed to meet the challenges of global citizenship. In this regard, ESD's priority goal is to promote "critical and systemic thinking, analytical problem-solving, creativity, working collaboratively and making decisions in the face of uncertainty, and understanding of the interconnectedness of global challenges and responsibilities emanating from such awareness" (point 8, p. 2). Based on this, and given its enormous potential, CT has become an essential skill to promote sustainability [5-8].

Recognition of the importance of CT goes back more than 2500 years, to Plato and Socrates, who taught their disciples in a nondogmatic way, subjecting their ideas to rigorous and critical questioning. Since then, numerous studies have demonstrated and highlighted the importance of CT in education $[9,10]$. Despite this, it has not been very present in educational practice due to different factors, such as the high number of students in the 
classroom, an educational curriculum full of content, the inadequate use of information and communication technologies and the lack of teacher training [11].

Currently, there are different definitions of $\mathrm{CT}$, but most of them agree that it is reflective and reasoned thinking focused on deciding what to do [12,13]. This thinking is directed towards achieving a specific goal, making decisions or solving problems [14,15]. Based on this, it is possible to state that it is skilful and responsible thinking which facilitates good judgment and is based on context-sensitive criteria. The ability to think critically is identified as an essential life skill $[12,16]$. Moreover, with these competences, it is possible for people to perform basic but important activities, for example, distinguishing whether information received from the environment is correct or false. However, CT is not only relevant for the individual, but also for the progress of society, having become one of the fundamental pillars of the new knowledge-based economy [17]. In education, CT has been shown to significantly improve students' academic performance [18] and is an ideal tool for educating the minds of children and adolescents [19]. Basically, it facilitates them to solve problems in complex situations, as well as to relate effectively [20]. Therefore, teaching and learning to think critically is one of the most important goals of current educational systems [21,22].

Piergiovanni [23] argues that, in order to develop CT in the classroom, it is first necessary for the learner to have a deep understanding of the subject matter. However, other researchers (e.g., [24]) highlight that the capacity for prior critical reflection is a key component of transformative learning, and argue that experiences that are not reflectively examined do not lead to meaningful learning [25]. Therefore, and considering that the development of CT is not acquired "naturally or casually", there is a need to stimulate it, for example, by encouraging students to reflect on what they observe or think they know in order to construct new knowledge, solve problems and/or make good decisions.

It seems that CT is influenced by the individual characteristics of the person [26], especially in childhood and adolescence [27]. Despite this, the formation of personality and the elements that constitute it, such as self-esteem and self-concept, have received little attention in the field of education [28].

\section{Effective Personality and Critical Thinking}

EP is a theoretical-empirical construct that brings together the approaches developed by Bandura on self-efficacy [29], Gardner's intelligence [30], the studies and research on emotional intelligence by Salovey and Mayer [31], the emotional intelligence model by Bar-On [32] and the maturity model — based on competence — developed by Carpenter [33] and Garmez and Mansten [34]. EP is synthesised in four dimensions of the self: the strengths dimension (self-concept and self-esteem), the demands dimension (motivation, attribution and expectations), the challenges dimension (coping and decision-making) and the relationship dimension of the self (empathy, assertiveness and communication) [35]. Therefore, a person with EP knows and values him/herself (self-concept and self-esteem) and is in a constant process of maturation, with the capacity (intelligence) to achieve (effectiveness) what he/she desires (motivation) and expects (expectation). To do so, the individual employs the best means (selection), uses the CT (strategy), selects the most feasible ways (efficiency) and controls the causes of their achievement (success or failure), facing the personal, circumstantial and social difficulties that arise (coping). In this way, they make the right decisions, without detriment to their good relationships with others (empathy and communication) and without giving up their personal aspirations (assertiveness) [36,37]. EP answers the following questions: Who am I? How do I value myself? What do I want? What expectations do I have of achieving it? On what or on whom does its successful achievement depend? What problems do I have in achieving the objectives? How do I make decisions? How do I communicate with others? How do I put myself in the place of the other? How do I interact without ceasing to be myself? [38]. In short, an effective person is one who manages without major difficulties in the various areas of life, whether personal, academic and/or social. 
For two decades, Martín del Buey et al. [39] have addressed EP especially as a construct in which personality traits are related to effective professional or academic behaviour. However, few studies have analysed its importance in the education of children and young people, specifically in the learning of traits such as self-efficacy, empathy, assertiveness, communication skills, coping with problems and self-esteem. All these skills, as experts argue $[2,40]$, need to be developed from the early stages of education in the classroom using pedagogical methodologies such as collaborative and experiential learning.

Martín del Buey et al. [37] explain that the EP construct is synthesised in four dimensions of the "self" that function interactively, influencing each other and generating a type of response (behaviour) which is considered effective in coping with the challenges faced by the person:

(1) Strengths (self-concept, self-esteem, self-confidence). Self-concept is understood as the cognitive aspects that a person has of him/herself [36]. Self-esteem, on the other hand, refers to the value that individuals place on themselves and which contributes to their potential to be effective [41]. Authors, such as Bhagat [42], Clemes and Bean [43] and González-Váquez [44] argue that one of the main factors influencing students' academic performance is their level of self-esteem, and that students with low selfesteem tend to feel dissatisfied in school. Asakereh and Yousofi [45] further add that low self-esteem can lead to anxiety and depression. Self-confidence, on the other hand, is a feeling of trust in one's own ability. This involves, for example, performing activities freely, accepting and respecting other people, motivating oneself to perform at a high level and realising one's own strengths and weaknesses [46]. Consequently, self-confidence influences motivation and the search for the necessary resources to act appropriately in a situation.

(2) Demands (motivation, attribution, expectations). The factors in this dimension are structured within temporal coordinates. Motivation appears as the person's intentionality in the present, and is linked to enthusiasm. Expectation corresponds to the future and attribution to the vision of what the person has done.

(3) Challenges (problem coping and decision-making). This is an indicator of the degree of effectiveness in coping with problems. Specifically, it refers to the ability to use effective coping strategies and to make decisions with a positive attitude and adjusted to the demands of a given situation. In other words, the person searches for as much information as possible and analyses the consequences of his/her decisions with a willingness to learn from experience.

(4) The relationships of the self (empathy, assertiveness, communication). This is an indicator of the degree to which a person is able to relate to others and express their opinions assertively. It involves communication skills, empathy and assertiveness. This dimension shows the link between self-perception and the ability to establish and maintain relationships with others, as well as expectations of success in future social relationships.

The possible relationships between EP and CT have been little researched both internationally and in a Spanish context. In this line, Asakereh and Yousofi [45] conducted an investigation to analyse the possible relationships between reflective thinking, self-efficacy, self-esteem and academic performance in 132 Iranian students. The results of the study revealed that there were statistically significant relationships between self-efficacy, selfesteem and academic performance of the participants, but not between reflective thinking and self-esteem. Lin et al. [47] also showed that self-esteem can contribute positively to higher efficacy in decision-making, and that people with higher self-esteem are more confident and have more positive attitudes, for example, in career choice. In a recent study with medical students, Khavanin et al. [48] conclude that self-esteem is an essential indicator of people's mental health, and that it can vary from one individual to another [49]. These researchers concluded that identifying barriers to the development of CT could help students to increase and improve it. Given the importance of $\mathrm{CT}$ for learning and for 
making relevant decisions in their daily lives, it is necessary to determine the factors that influence students' CT development.

In Spain, one of the few research studies that comes close to analysing the relationship between EP and CT is the study by Chiva-Bartoll et al. [36]. The authors argue that the development of EP is one of the goals of university education in the 21st century, and investigate how service-learning can contribute to the development of EP in future Physical Education teachers. In the study, they specifically allude to the importance of CT in relation to EP and the effects of service-learning methodology. Guerrero et al. [50] analysed the personal and social competences of 250 Spanish adolescents diagnosed with attention deficit hyperactivity disorder (ADHD) using a questionnaire based on the EP construct model of Martín del Buey and Martín-Palacio [27]. The results show that males obtain higher scores than females diagnosed with the same disorder.

\section{Materials and Methods}

Based on this background, the objectives of this study were: (1) to learn about possible relationships between CT and EP and (2) to determine to what extent EP predicts the development of CT in children and adolescents. To this end, the following research questions were posed: (1) What relationships occur between EP and CT? (2) To what extent does EP predict the development of CT in children and adolescents?

The research approach was quantitative, descriptive, correlational and predictive. The aim was to determine the degree of relationship between the two variables of the study: CT (dependent variable) and EP (independent variable). In addition, CT was analysed considering the educational stage and sex of the participants.

\subsection{Measurement Instruments}

The measurement instruments were:

(1) The Critical Thinking Disposition Inventory, adapted from Facione and Facione's Critical Thinking Disposition Inventory [51], consisting of 6 dimensions (analysis, inference, explanation, interpretation, evaluation and self-regulation) and 10 items (Table 1). The internal consistency of the instrument's items was estimated using Cronbach's alpha method. The reliability coefficient obtained in the analysis was 0.91 . This value was highly significant, indicating that the degree of homogeneity among the items was quite acceptable.

(2) Fueyo's Efficacy Personality Questionnaire [35]. It was adapted to the purposes and context of the study. It consisted of 4 dimensions (the strengths dimension, the demands dimension, the challenges dimension and the relationships dimension of the self) and 10 items (Table 2). The instrument obtained an original reliability index of 0.797 .

Each item was measured according to a five-point Likert-type scale, taking into account the frequency of the ability or trait $(1=$ Never, $2=$ Rarely, $3=$ Sometimes, $4=$ Almost always and 5 = Always). Although both instruments were extensively tested and validated, due to the adaptation carried out, the validity analysis of the total number of items was carried out. For this purpose, principal component factor analysis was conducted for the total sample, obtaining adequate values in the KMO index (0.95) and in Barlett's test of sphericity $\left(\chi^{2} 190=15,445.70 ; p<0.000\right)$. The confirmatory factor analysis of the hypothesised theoretical model was then carried out for the total sample considering the two theoretical dimensions (CT and EP). On this basis, correct fit indices were obtained $\left(x^{2} / \mathrm{gl}=1587.3 ; \mathrm{PCFI}=0.638 ; \mathrm{CFI}=0.753 ; \mathrm{FMIN}=5.731 ; \mathrm{RMSEA}=0.078\right)$. In addition, Cronbach's Alpha yielded a value of 0.93 for the CT items and 0.90 for the EP. 
Table 1. Dimensions of the Critical Thinking Disposition Inventory [51].

\begin{tabular}{|c|c|c|c|}
\hline Dimensions of CT & Definition & & Questionnaire Items \\
\hline Analysis & $\begin{array}{l}\text { Identify actual and assumed inferential relationships between } \\
\text { statements, questions, concepts, descriptions or other forms of } \\
\text { representation intended to express beliefs, judgements, experiences, } \\
\text { reasons, information or opinions. Examine ideas, detect and } \\
\text { analyse arguments. }\end{array}$ & $\begin{array}{l}\bigcirc \\
\bigcirc \\
\bigcirc\end{array}$ & $\begin{array}{l}\text { Don't just learn by rote } \\
\text { Developing analytical skills } \\
\text { To create new knowledge and not just } \\
\text { repeat it by rote. }\end{array}$ \\
\hline Inference & $\begin{array}{l}\text { Assessment of the credibility of statements or other representations } \\
\text { describing a person's perception, experience, situation, judgement, } \\
\text { belief or opinion. Assessment of the logical strength of inferential } \\
\text { relationships, real or assumed, between statements, descriptions, } \\
\text { questions or other forms of representation. }\end{array}$ & $\bigcirc$ & $\begin{array}{l}\text { Relate subject topics to what is } \\
\text { happening in reality }\end{array}$ \\
\hline Explanation & $\begin{array}{l}\text { Ability to present the results of one's reasoning in a reflective and } \\
\text { coherent manner. This means being able to present to someone an } \\
\text { overview of the big picture to state and justify that reasoning in } \\
\text { terms of the evidence, conceptual, methodological, critical and } \\
\text { contextual considerations on which the results obtained were based, } \\
\text { and to present the reasoning in the form of sound arguments. }\end{array}$ & $\bigcirc$ & $\begin{array}{l}\text { To develop the ability to explain and } \\
\text { argue ideas clearly }\end{array}$ \\
\hline Interpretation & $\begin{array}{l}\text { Understanding and expressing the meaning or relevance of a wide } \\
\text { variety of experiences, situations, data, events, judgements, } \\
\text { conventions, beliefs, rules, procedures or criteria. Includes the } \\
\text { subskills of categorisation, meaning decoding and clarification } \\
\text { sense. }\end{array}$ & 0 & $\begin{array}{l}\text { Know and learn the subject matter of the } \\
\text { course } \\
\text { Understand, distinguish and express } \\
\text { main ideas and judgements. }\end{array}$ \\
\hline Evaluation & $\begin{array}{l}\text { Assessment of the credibility of a person's statements or other } \\
\text { representations, perception, experience, situation, judgement, belief } \\
\text { or opinion. Assessment of the logical strength of inferential } \\
\text { relationships, real or assumed, between statements, descriptions, } \\
\text { questions or other forms of representation. }\end{array}$ & $\bigcirc$ & Being critical, self-critical and reflective \\
\hline Self-regulation & $\begin{array}{l}\text { Self-conscious monitoring of one's own cognitive activities, the } \\
\text { elements used in those activities and the results obtained, applying } \\
\text { particularly analytical and evaluative skills to one's own inferential } \\
\text { judgements. Questioning, confirming, validating or correcting } \\
\text { one's reasoning or results. }\end{array}$ & $\begin{array}{l}\bigcirc \\
\bigcirc\end{array}$ & $\begin{array}{l}\text { Research } \\
\text { Inquire outside the classroom about } \\
\text { subject content }\end{array}$ \\
\hline
\end{tabular}

Table 2. Dimensions of the effective personality.

$\begin{array}{ccc}\begin{array}{c}\text { Dimensions of the Effective } \\ \text { Personality }\end{array} & \text { Definition } & \text { Questionnaire Items }\end{array}$

\begin{tabular}{clll}
\hline & $\begin{array}{l}\text { Self-esteem and self-concept. Ability to understand } \\
\text { how people see themselves and how the opinion } \\
\text { of others influences their idea of themselves, of } \\
\text { their identity: declarative memory (self-concept) } \\
\text { and emotional memory (self-esteem). }\end{array}$ & $\begin{array}{l}\bigcirc \\
0\end{array}$ & $\begin{array}{l}\text { Being self-demanding } \\
\text { Being able to set boundaries } \\
\text { Having self-control } \\
\text { Having balance } \\
\text { Developing positive self-esteem } \\
\text { Having self-confidence }\end{array}$ \\
\hline Challenges & Problem solving and decision-making skills & $\bigcirc$ & Being self-sufficient \\
\hline Relational & $\begin{array}{l}\text { Relationship building, empathy, assertiveness and } \\
\text { communication skills }\end{array}$ & $\bigcirc$ & $\begin{array}{l}\text { Being respectful and demanding } \\
\text { respect } \\
\text { Being impartial }\end{array}$ \\
\hline Demands & Expectations, motivation, attribution & $\bigcirc$ & Being enthusiastic
\end{tabular}

\subsection{Sample}

For the selection of the sample, the purposive and convenience sampling technique was used, considering the accessibility of the educational centres. A total of 562 students from five Primary and Secondary schools in the province of Alicante (Spain) participated in the study. Of these, $61.3 \%(n=345)$ were female and $38.7 \%(n=217)$ were male. Regarding the educational stage, $57.7 \%$ were in the fifth grade of Primary education $(n=324)$ and 
were 10 years old; and $42.3 \%(n=238)$ were in the third grade of Secondary education and were 14 years old.

\subsection{Procedure}

Once the study was designed, the research group met with the headteachers of the five schools and explained the aims of the research. Once the headteachers had given permission for the students to participate in the study, the tutors were contacted. A briefing session was held with them and then with the students, who were informed about the purpose of the research and about the anonymous and voluntary nature of their participation. Subsequently, informed consent was obtained from the parents. Once this stage was completed, the instruments were created in the survey administration tool Google Forms, and the web links were sent using the schools' virtual platform. The participants completed the questionnaire during tutoring hours, individually and in the presence of one of the members of the research group. The instructions for filling in the questionnaire were explained to them. The response time was approximately $25 \mathrm{~min}$ for both instruments. The study complied with the ethical principles of the Declaration of Helsinki, and the voluntary nature of the students' participation was guaranteed at all times, as well as the anonymity and confidentiality of the information provided. No questionnaires had to be eliminated, as they had all been duly completed. Once the data had been collected, they were analysed using the IBM-SPSS Statistics-23 statistical package. The statistical analysis was carried out using bivariate and multivariate techniques. Thus, correlation analysis was performed using Spearman's Rho coefficient, because the variables did not follow normality or were not ordinal in nature, and multiple linear regression analysis was carried out to examine the dependent variable of the sample. In addition, stepwise multiple linear regression analysis was used to examine which items of the EP component influenced CT. Finally, the dummy variables (sex and educational stage) were analysed to determine whether there were differences according to sex and educational stage.

\section{Results}

\subsection{The Relationship between Effective Personality and Critical Thinking}

Bivariate correlation analysis shows the existence of a significant linear correlation between all pairs of EP and CT items. These correlations are significant at the $99 \%$ confidence level, and all of them are positive. The values of both variables evidence that there are no multicollinearity problems between the pairs of items ${ }^{*} p<0.05^{* *} p<0.01$ ) (Table 3). Therefore, the higher the degree of agreement with each of the items that make up the EP component, the higher the degree of agreement with the CT.

Furthermore, Spearman's Rho analysis demonstrates that the most significant correlations occur between CT and the following EP items: "being enthusiastic" (0.549), "developing positive self-esteem" (0.546), "having self-confidence" (0.533), "having balance" (0.515) and "having self-control" (0.510) (Table 4). However, the correlations with the remaining items ("being respectful and demanding respect", "being impartial", "being able to set boundaries", "being self-sufficient" and "being self-demanding") are also positive (Table 4). 
Table 3. Correlation between the items that make up the effective personality and critical thinking.

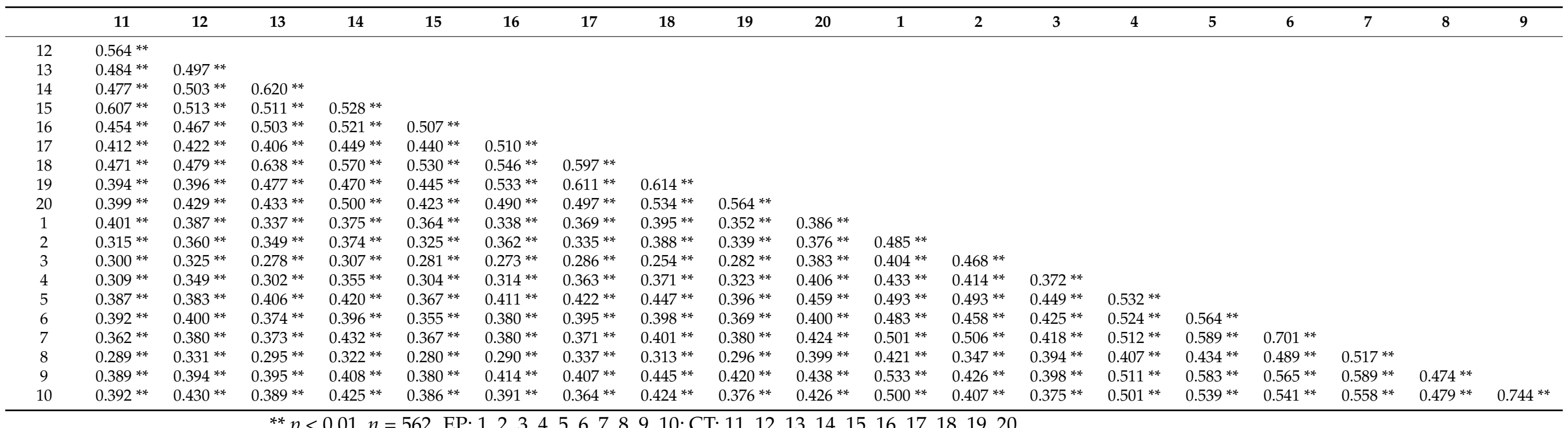

** $p<0.01, n=562$. EP: 1, 2, 3, 4, 5, 6, 7, 8, 9, 10; CT: 11, 12, 13, 14, 15, 16, 17, 18, 19, 20. 
Table 4. Significant correlations between effective personality and critical thinking.

\begin{tabular}{cc}
\hline Effective Personality & Critical Thinking \\
\hline Being respectful and demanding respect & $0.493^{* *}$ \\
Being impartial & $0.474^{* *}$ \\
Being self-demanding & $0.394^{* *}$ \\
Being able to set boundaries & $0.451^{* *}$ \\
Being enthusiastic & $0.549^{* *}$ \\
Having self-control & $0.510^{* *}$ \\
Having balance & $0.515^{* *}$ \\
Being self-sufficient & $0.420^{* *}$ \\
Developing positive self-esteem & $0.546^{* *}$ \\
Having self-confidence & $0.533^{* *}$ \\
\hline$* *<0.01, n=562$. &
\end{tabular}

When the correlation between the two dimensions (all items of the CT and the EP) is analysed, a Spearman $r=0.664$ is obtained (Table 5). This shows that there is a positive and significant correlation between the two variables.

Table 5. Correlation between the self-esteem dimension and the critical thinking dimension. Sample of students.

\begin{tabular}{lc}
\hline & Critical Thinking \\
\hline Effective personality & $0.664^{* *}$ \\
\hline$* * p<01, n=562$. &
\end{tabular}

In order to visually establish how $\mathrm{CT}$ is associated or correlated with EP, we observe, in Figure 1, the scatter plot according to educational stage.

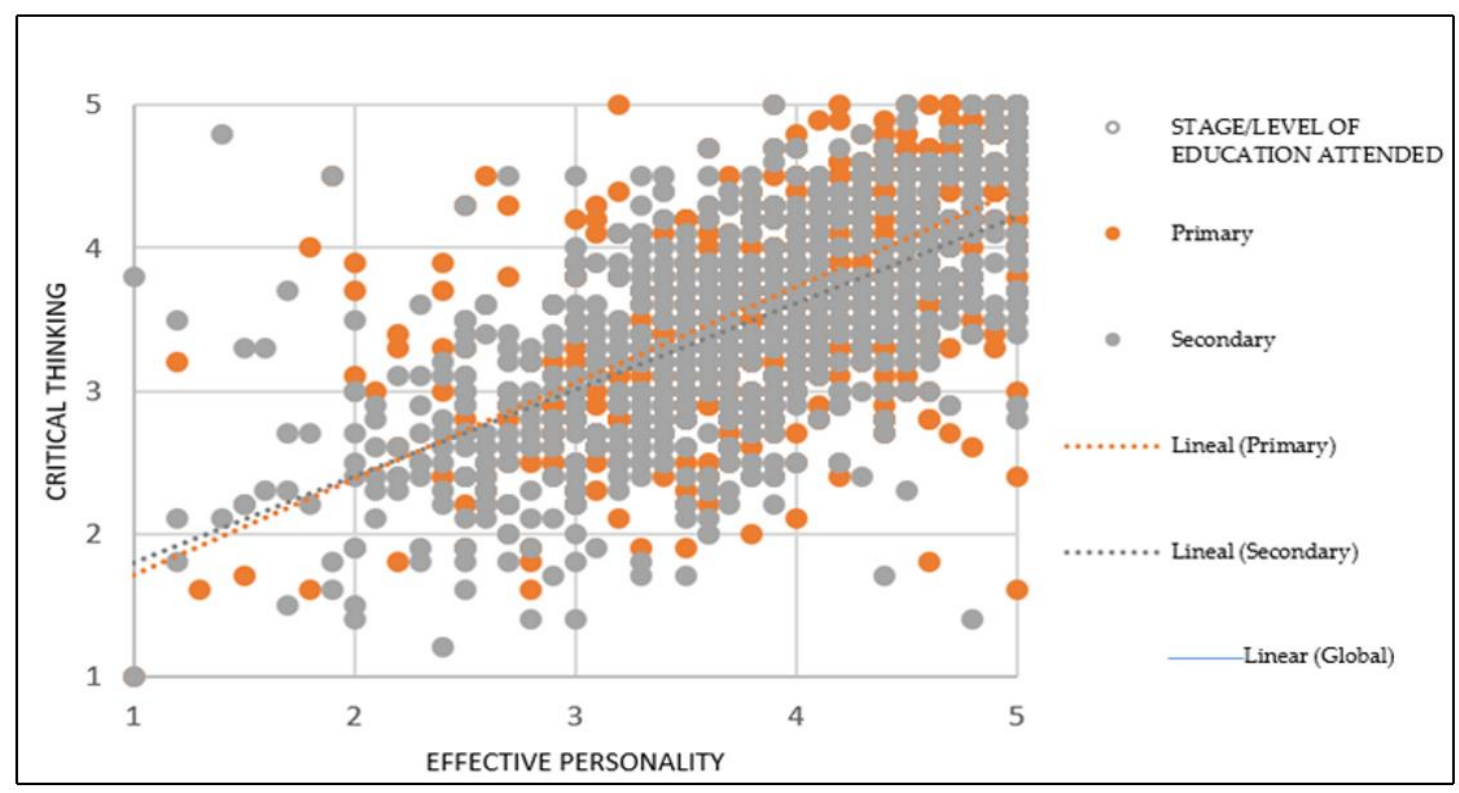

Figure 1. Critical thinking and effective personality by stage of education.

The graph above visually represents the number of cases that reflect those scores given to the CT and EP variables of the students participating in the study. The point cloud shows a clear correlation, with a linear trend, between the two variables. When projecting the linear equation, it is observed that there is a direct linear trend in the two school stages, as well as in the total sample. Based on this, it can be concluded that the higher the EP scores, the higher the CT scores will be. Moreover, it is striking that the slope of the straight line 
through the points is more accentuated in the group of students in Primary Education than in Secondary Education.

\subsection{Linear Regression Analysis of Critical Thinking and Effective Personality}

In order to gain a better understanding of how EP influences $\mathrm{CT}$, multiple linear regression analysis was carried out. In this way, the predictive model was designed and the degree to which the variables that make up the EP had an impact on the student's CT was determined (Table 6).

Table 6. Regression model predicting critical thinking by means of effective personality.

\begin{tabular}{|c|c|c|c|c|c|c|}
\hline & & $\begin{array}{l}\text { Unstandardised } \\
\text { Coefficients }\end{array}$ & $\begin{array}{c}\text { Standardised } \\
\text { Coefficients }\end{array}$ & & & \\
\hline Model & Items & B & Beta & $\mathbf{t}$ & Sig. & Model \\
\hline 1 & Being enthusiastic & 3.882 & 0.541 & 24.534 & 0.000 & $\mathrm{R} 2=0.293 \mathrm{~F}(1,1451)=601.93$ **. \\
\hline \multirow[b]{2}{*}{2} & Being enthusiastic & 2.579 & 0.360 & 14.488 & 0.000 & \multirow{2}{*}{$\mathrm{R} 2=0.371 \mathrm{~F}(2,1450)=418.50 * *$} \\
\hline & Having self-confidence & 2.383 & 0.334 & 13.438 & 0.000 & \\
\hline \multirow{3}{*}{3} & Being enthusiastic & 2.022 & 0.282 & 10.881 & 0.000 & \multirow{3}{*}{$\begin{aligned} \mathrm{R} 2= & 0.401 \mathrm{~F}(3,1449)=323.5^{* *} \mathrm{R} 2 \\
& =0.401 \mathrm{~F}(3,1449)=323.5\end{aligned}$} \\
\hline & Having self-confidence & 2.115 & 0.296 & 12.016 & 0.000 & \\
\hline & Being impartial & 1.407 & 0.201 & 8.476 & 0.000 & \\
\hline \multirow{4}{*}{4} & Being enthusiastic & 1.765 & 0.246 & 9.384 & 0.000 & \multirow{4}{*}{$\mathrm{R} 2=0.417 \mathrm{~F}(4,1448)=258.43^{* *}$} \\
\hline & Having self-confidence & 1.816 & 0.254 & 10.066 & 0.000 & \\
\hline & Being impartial & 1.133 & 0.162 & 6.668 & 0.000 & \\
\hline & $\begin{array}{l}\text { Being respectful and } \\
\text { demanding respect }\end{array}$ & 1.346 & 0.156 & 6.175 & 0.000 & \\
\hline \multirow{5}{*}{5} & Being enthusiastic & 1.461 & 0.204 & 7.436 & 0.000 & \multirow{5}{*}{$\mathrm{R} 2=0.426 \mathrm{~F}(5,1447)=214.95^{* *}$} \\
\hline & Having self-confidence & 1.586 & 0.222 & 8.576 & 0.000 & \\
\hline & Being impartial & 1.009 & 0.144 & 5.920 & 0.000 & \\
\hline & $\begin{array}{l}\text { Being respectful and } \\
\text { demanding respect }\end{array}$ & 1.215 & 0.141 & 5.579 & 0.000 & \\
\hline & Having self-control & 0.977 & 0.131 & 4.936 & 0.000 & \\
\hline \multirow{6}{*}{6} & Being enthusiastic & 1.313 & 0.183 & 6.577 & 0.000 & \multirow{6}{*}{$\mathrm{R} 2=0.432 \mathrm{~F}(6,1446)=183.27^{* *}$} \\
\hline & Having self-confidence & 1.098 & 0.154 & 4.876 & 0.000 & \\
\hline & Being impartial & 1.007 & 0.144 & 5.940 & 0.000 & \\
\hline & $\begin{array}{l}\text { Being respectful and } \\
\text { demanding respect }\end{array}$ & 1.072 & 0.124 & 4.868 & 0.000 & \\
\hline & Having self-control & 0.877 & 0.117 & 4.412 & 0.000 & \\
\hline & $\begin{array}{l}\text { Developing positive } \\
\text { self-esteem }\end{array}$ & 0.889 & 0.125 & 3.768 & 0.000 & \\
\hline \multirow{7}{*}{7} & Being enthusiastic & 1.281 & 0.179 & 6.409 & 0.000 & \multirow{7}{*}{$\mathrm{R} 2=0.434 \mathrm{~F}(7,1445)=158.08 * *$} \\
\hline & Having self-confidence & 1.025 & 0.143 & 4.510 & 0.000 & \\
\hline & Being impartial & 0.994 & 0.142 & 5.865 & 0.000 & \\
\hline & $\begin{array}{l}\text { Being respectful and } \\
\text { demanding respect }\end{array}$ & 1.017 & 0.118 & 4.595 & 0.000 & \\
\hline & Having self-control & 0.778 & 0.104 & 3.820 & 0.000 & \\
\hline & $\begin{array}{l}\text { Developing positive } \\
\text { self-esteem }\end{array}$ & 0.868 & 0.122 & 3.681 & 0.000 & \\
\hline & Being self-sufficient & 0.400 & 0.054 & 2.208 & 0.027 & \\
\hline
\end{tabular}

** $p<0.01, n=562$.

The model reflects the set of items that are most favourable for recognising the prediction of the dependent variable (CT) and disregards those that do not influence it. The results of the stepwise regression analysis show that the more items are added to the model, the more explanatory power it has until the best model incorporating the set of items is obtained. The last model predicts $43.4 \%$ of the CT component $(\mathrm{R} 2=0.434 \mathrm{~F}(7,1445)=$ $\left.158.08^{* *}\right)$. This variability is significant at a $99 \%$ confidence level, which implies that the items involved in EP are significant and positive.

\subsection{The Model When the Sex Variable Intervenes}

In order to find out whether the student's sex influences the CT, the predictive model is replicated including the independent variable "sex" (dummy). 
The analysis shows that when "sex" intervenes, the variance of the fit does not change; on the contrary, the variance is the same as that of CT $(43.4 \%)(\mathrm{R} 2=0.434 \mathrm{~F}(8,1444)=$ $\left.138.28^{* *}\right)($ Table 7). Therefore, it is possible to state that this variance is significant at a $99 \%$ confidence level. In sum, all the EP items are significant and positive, as already found in Figure 1.

Table 7. Regression model predicting critical thinking when the students' sex intervenes.

\begin{tabular}{|c|c|c|c|c|c|c|}
\hline & & $\begin{array}{l}\text { Unstandardised } \\
\text { Coefficients }\end{array}$ & $\begin{array}{c}\text { Standardised } \\
\text { Coefficients }\end{array}$ & & & \\
\hline Model & Items & B & Beta & $\mathbf{t}$ & Sig. & Model \\
\hline 1 & Sex & 0.025 & 0.002 & 0.059 & 0.953 & $\mathrm{R} 2=0.200 \mathrm{~F}(1,1451)=0.003$ \\
\hline 2 & $\begin{array}{c}\text { Sex } \\
\text { Being enthusiastic }\end{array}$ & $\begin{array}{c}-0.049 \\
3.882\end{array}$ & $\begin{array}{c}-0.003 \\
0.542\end{array}$ & $\begin{array}{l}-0.135 \\
24.526\end{array}$ & $\begin{array}{l}0.893 \\
0.000\end{array}$ & $\mathrm{R} 2=0.293 \mathrm{~F}(2,1450)=300.77^{* *}$ \\
\hline 3 & $\begin{array}{c}\text { Sex } \\
\text { Being enthusiastic } \\
\text { Having self-confidence }\end{array}$ & $\begin{array}{l}-0.181 \\
2.578 \\
2.386\end{array}$ & $\begin{array}{c}-0.011 \\
0.360 \\
0.334\end{array}$ & $\begin{array}{l}-0.532 \\
14.479 \\
13.444\end{array}$ & $\begin{array}{l}0.595 \\
0.000 \\
0.000\end{array}$ & $\mathrm{R} 2=0.372 \mathrm{~F}(3,1449)=285.62 * *$ \\
\hline 4 & $\begin{array}{l}\text { Sex } \\
\text { Being enthusiastic } \\
\text { Having self-confidence } \\
\text { Being impartial }\end{array}$ & $\begin{array}{l}-0.036 \\
2.022 \\
2.116 \\
1.406\end{array}$ & $\begin{array}{l}-0.002 \\
0.282 \\
0.296 \\
0.201\end{array}$ & $\begin{array}{c}-0.109 \\
10.878 \\
12.007 \\
8.456\end{array}$ & $\begin{array}{l}0.913 \\
0.000 \\
0.000 \\
0.000\end{array}$ & $\mathrm{R} 2=0.401 \mathrm{~F}(4,1448)=242.52 * *$ \\
\hline 5 & $\begin{array}{c}\text { Sex } \\
\text { Being enthusiastic } \\
\text { Having self-confidence } \\
\text { Being impartial } \\
\text { Being respectful and } \\
\text { demanding respect }\end{array}$ & $\begin{array}{l}0.092 \\
1.764 \\
1.813 \\
1.134 \\
1.350\end{array}$ & $\begin{array}{l}0.006 \\
0.246 \\
0.254 \\
0.162 \\
0.156\end{array}$ & $\begin{array}{c}0.281 \\
9.372 \\
10.033 \\
6.671 \\
6.179\end{array}$ & $\begin{array}{l}0.779 \\
0.000 \\
0.000 \\
0.000 \\
0.000\end{array}$ & $\mathrm{R} 2=0.415 \mathrm{~F}(5,1447)=206.63^{* *}$ \\
\hline 6 & $\begin{array}{c}\text { Sex } \\
\text { Being enthusiastic } \\
\text { Having self-confidence } \\
\text { Being impartial } \\
\text { Being respectful and } \\
\text { demanding respect } \\
\text { Having self-control }\end{array}$ & $\begin{array}{l}0.110 \\
1.460 \\
1.583 \\
1.011\end{array}$ & $\begin{array}{l}0.007 \\
0.204 \\
0.222 \\
0.144\end{array}$ & $\begin{array}{l}0.336 \\
7.422 \\
8.543 \\
5.926\end{array}$ & $\begin{array}{l}0.737 \\
0.000 \\
0.000 \\
0.000\end{array}$ & $\mathrm{R} 2=0.426 \mathrm{~F}(6,1446)=179.04^{* *}$ \\
\hline 7 & $\begin{array}{c}\text { Sex } \\
\text { Being enthusiastic } \\
\text { Having self-confidence } \\
\text { Being impartial } \\
\text { Being respectful and } \\
\text { demanding respect } \\
\text { Having self-control } \\
\text { Developing positive } \\
\text { self-esteem }\end{array}$ & $\begin{array}{l}0.083 \\
1.312 \\
1.096 \\
1.009 \\
1.076 \\
0.878 \\
0.888\end{array}$ & $\begin{array}{l}0.005 \\
0.183 \\
0.153 \\
0.144 \\
0.124 \\
0.117 \\
0.125\end{array}$ & $\begin{array}{l}0.254 \\
6.568 \\
4.864 \\
5.943 \\
4.873 \\
4.414 \\
3.760\end{array}$ & $\begin{array}{l}0.800 \\
0.000 \\
0.000 \\
0.000 \\
0.000\end{array}$ & $\mathrm{R} 2=0.432 \mathrm{~F}(7,1445)=156.87^{* *}$ \\
\hline 8 & $\begin{array}{c}\text { Sex } \\
\text { Being enthusiastic } \\
\text { Having self-confidence } \\
\text { Being impartial } \\
\text { Being respectful and } \\
\text { demanding respect } \\
\text { Having self-control } \\
\text { Developing positive } \\
\text { self-esteem } \\
\text { Being self-sufficient }\end{array}$ & $\begin{array}{l}0.161 \\
1.278 \\
1.020 \\
0.996 \\
1.023 \\
0.777 \\
0.865\end{array}$ & $\begin{array}{l}0.010 \\
0.178 \\
0.143 \\
0.142 \\
0.118\end{array}$ & $\begin{array}{l}0.493 \\
6.391 \\
4.480 \\
5.875 \\
4.613\end{array}$ & $\begin{array}{l}0.622 \\
0.000 \\
0.000 \\
0.000 \\
0.000\end{array}$ & $\mathrm{R} 2=0.434 \mathrm{~F}(8,1444)=138.28^{* *}$ \\
\hline
\end{tabular}

** $p<0.01, n=562$.

In terms of the relevance of each EP factor, the following graph reflects the prevalence of the items, recognising that sex does not play a significant role in the influence of EP on CT (Figure 2): 


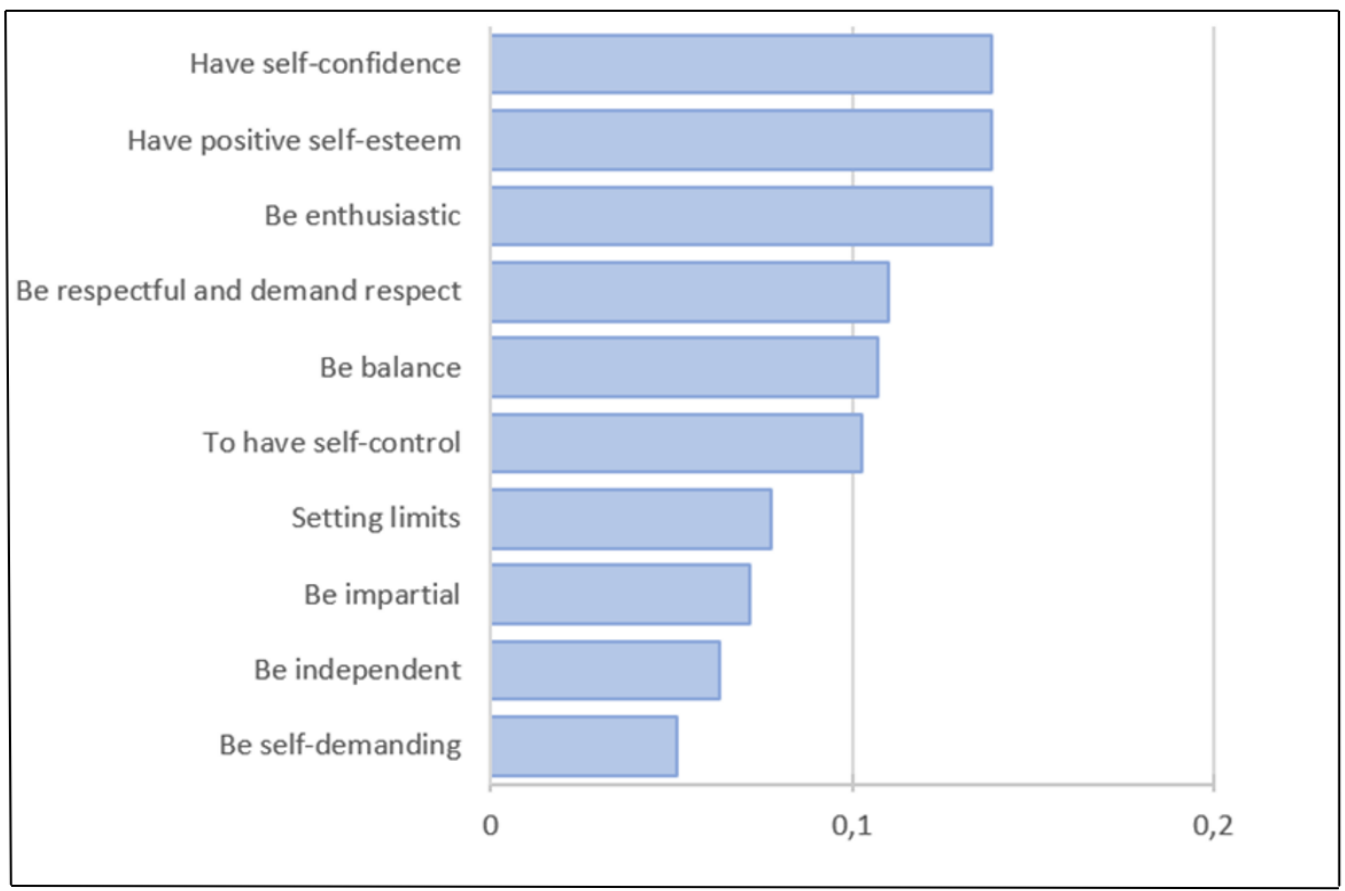

Figure 2. Importance of predictors influencing CT.

\subsection{The Model When the Educational Stage Intervenes}

In order to determine more specifically to what extent the model is or is not conditioned when the educational stage of the participating student body is involved, the analysis of the independent variable educational stage (dummy) is included: Primary Education and Secondary Education (Table 8).

Table 8. Regression model predicting critical thinking when the educational stage intervenes.

\begin{tabular}{|c|c|c|c|c|c|c|}
\hline & & $\begin{array}{l}\text { Unstandardised } \\
\text { Coefficients }\end{array}$ & $\begin{array}{c}\text { Standardised } \\
\text { Coefficients }\end{array}$ & & & \\
\hline Model & Items & B & Beta & $\mathbf{t}$ & Sig. & Model \\
\hline 1 & PRIMARY STAGE & 2.786 & 0.171 & 6.623 & 0.000 & $\mathrm{R} 2=0.029 \mathrm{~F}(1,1451)=43.858^{* *}$ \\
\hline \multirow{2}{*}{2} & PRIMARY STAGE & 1.087 & 0.067 & 2.974 & 0.003 & \multirow{2}{*}{$\mathrm{R} 2=0.297 \mathrm{~F}(2,1450)=306.19^{* *}$} \\
\hline & Developing positive self-esteem & 3.748 & 0.528 & 23.492 & 0.000 & \\
\hline \multirow{3}{*}{3} & PRIMARY STAGE & 0.531 & 0.033 & 1.521 & 0.128 & \multirow{3}{*}{$\mathrm{R} 2=0.369 \mathrm{~F}(3,1449)=282.37$ ** } \\
\hline & Developing positive self-esteem & 2.384 & 0.336 & 12.909 & 0.000 & \\
\hline & Being enthusiastic & 2.406 & 0.336 & 12.858 & 0.000 & \\
\hline \multirow{4}{*}{4} & PRIMARY STAGE & 0.525 & 0.032 & 1.543 & 0.123 & \multirow{4}{*}{$\mathrm{R} 2=0.400 \mathrm{~F}(4,1448)=241.07$ ** } \\
\hline & Developing positive self-esteem & 2.116 & 0.298 & 11.571 & 0.000 & \\
\hline & Being enthusiastic & 1.852 & 0.258 & 9.565 & 0.000 & \\
\hline & Being impartial & 1.432 & 0.204 & 8.622 & 0.000 & \\
\hline \multirow{5}{*}{5} & PRIMARY STAGE & 0.541 & 0.033 & 1.607 & 0.108 & \multirow{5}{*}{$\mathrm{R} 2=0.414 \mathrm{~F}(5,1447)=204.52$ ** } \\
\hline & Developing positive self-esteem & 1.234 & 0.174 & 5.279 & 0.000 & \\
\hline & Being enthusiastic & 1.688 & 0.236 & 8.736 & 0.000 & \\
\hline & Being impartial & 1.341 & 0.191 & 8.140 & 0.000 & \\
\hline & Having self-confidence & 1.342 & 0.188 & 5.948 & 0.000 & \\
\hline \multirow{6}{*}{6} & PRIMARY STAGE & 0.586 & 0.036 & 1.757 & 0.079 & \multirow{6}{*}{$\mathrm{R} 2=0.423 \mathrm{~F}(6,1446)=178.39 * *$} \\
\hline & Developing positive self-esteem & 0.996 & 0.140 & 4.223 & 0.000 & \\
\hline & Being enthusiastic & 1.517 & 0.212 & 7.814 & 0.000 & \\
\hline & Being impartial & 1.114 & 0.159 & 6.601 & 0.000 & \\
\hline & Having self-confidence & 1.227 & 0.172 & 5.461 & 0.000 & \\
\hline & $\begin{array}{l}\text { Being respectful and demanding } \\
\text { respect }\end{array}$ & 1.175 & 0.136 & 5.328 & 0.000 & \\
\hline
\end{tabular}


Table 8. Cont.

\begin{tabular}{|c|c|c|c|c|c|c|}
\hline & & $\begin{array}{l}\text { Unstandardised } \\
\text { Coefficients }\end{array}$ & $\begin{array}{c}\text { Standardised } \\
\text { Coefficients }\end{array}$ & & & \\
\hline Model & Items & B & Beta & $\mathbf{t}$ & Sig. & Model \\
\hline \multirow{7}{*}{7} & PRIMARY STAGE & 0.665 & 0.041 & 2.004 & 0.045 & \multirow{7}{*}{$\mathrm{R} 2=0.431 \mathrm{~F}(7,1445)=157.87^{* *}$} \\
\hline & Developing positive self-esteem & 0.850 & 0.120 & 3.593 & 0.000 & \\
\hline & Being enthusiastic & 1.261 & 0.176 & 6.272 & 0.000 & \\
\hline & Being impartial & 1.002 & 0.143 & 5.912 & 0.000 & \\
\hline & Having self-confidence & 1.097 & 0.154 & 4.878 & 0.000 & \\
\hline & $\begin{array}{l}\text { Being respectful and demanding } \\
\text { respect }\end{array}$ & 1.081 & 0.125 & 4.913 & 0.000 & \\
\hline & Having self-control & 0.898 & 0.120 & 4.516 & 0.000 & \\
\hline \multirow{8}{*}{8} & PRIMARY STAGE & 0.743 & 0.046 & 2.232 & 0.026 & \multirow{8}{*}{$\mathrm{R} 2=0.436 \mathrm{~F}(8,1444)=139.33^{* *}$} \\
\hline & Developing positive self-esteem & 0.822 & 0116 & 3.478 & 0.001 & \\
\hline & Being enthusiastic & 1.220 & 0.170 . & 6.056 & 0.000 & \\
\hline & Being impartial & 0.986 & 0.141 & 5.827 & 0.000 & \\
\hline & Having self-confidence & 1.017 & 0.142 & 4.480 & 0.000 & \\
\hline & $\begin{array}{l}\text { Being respectful and demanding } \\
\text { respect }\end{array}$ & 1.021 & 0.118 & 4.622 & 0.000 & \\
\hline & Having self-control & 0.792 & 0.106 & 3.891 & 0.000 & \\
\hline & Being self-sufficient & 0.439 & 0.059 & 2.417 & 0.016 & \\
\hline
\end{tabular}

** $p<0.01, n=562$.

The results show that the variability of the fit increases, although not significantly, with $43.6 \%\left(\mathrm{R} 2=0.436 \mathrm{~F}(8,1444)=139.33^{* *}\right)$ of the variance of the CT. This variance is significant at a $99 \%$ confidence level; therefore, it is possible to state that the items involved in the EP are significant and positive. Based on this, it is inferred that $\mathrm{EP}$ has a greater influence on CT when the educational stage is involved. Figure 3 provides evidence that students in Primary Education obtain higher CT scores than students in Secondary Education.

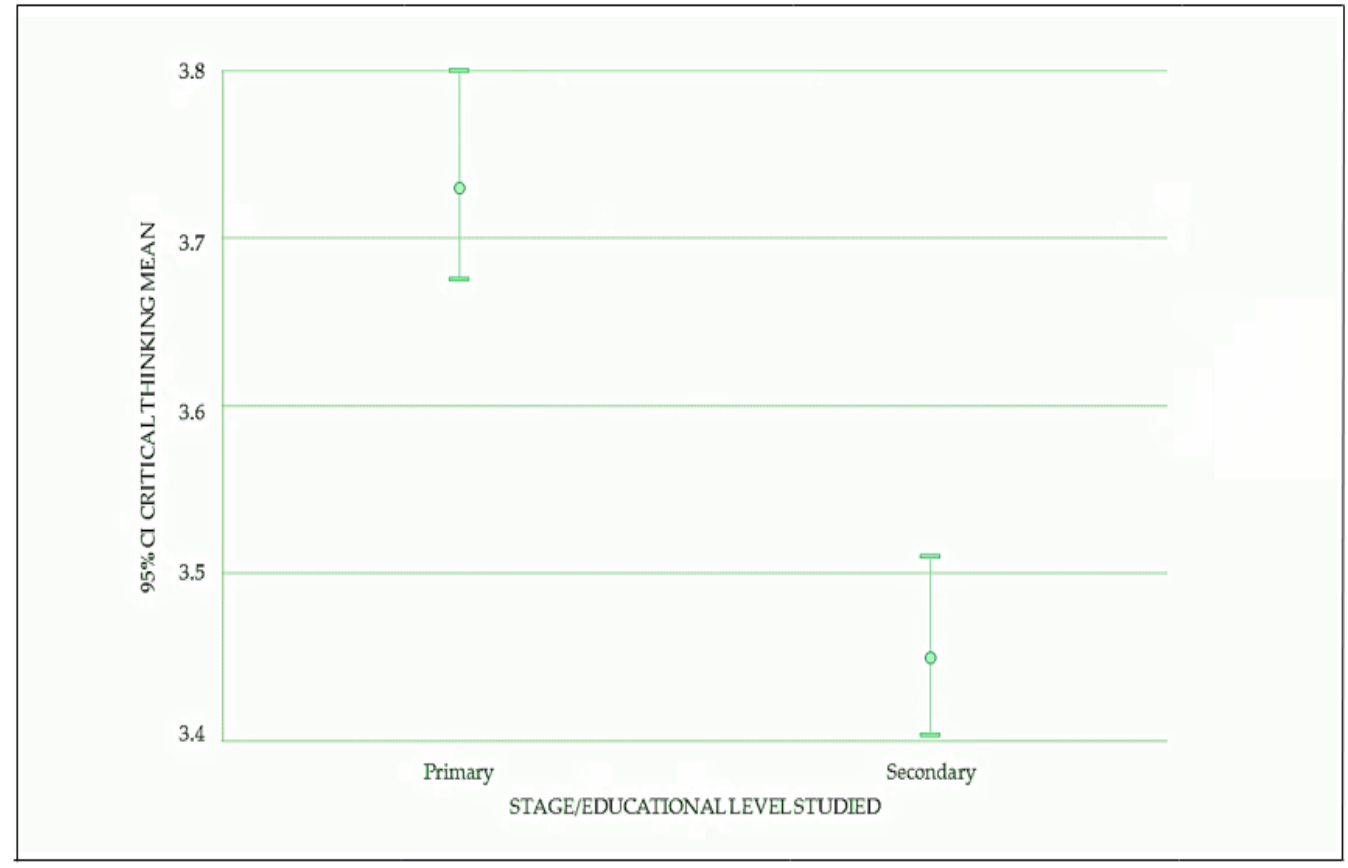

Figure 3. Influence of educational stage on critical thinking.

\section{Discussion and Conclusions}

The aims of this study were to find out the possible relationships between $\mathrm{CT}$ and $\mathrm{EP}$, and to determine the extent to which EP predicts the development of CT in Spanish students in Primary and Secondary Education. The findings prove that there is a positive and significant relationship at the $99 \%$ confidence level between EP and CT in students 
at both educational stages. These results are not easily comparable with other research, since no specific studies of this type have been carried out with children and adolescents in Spain, hence the originality of the article. However, some research has been carried out with university students. In this regard, our findings are consistent with the study by Asakereh and Yousofi [45], who found statistically significant relationships between some EP variables, especially self-esteem and self-efficacy, with reflective thinking. Likewise, it agrees with the research of Chiva-Bartoll et al. [36], who highlight the positive relationship between EP and CT, although punctually.

Despite the fact that the relationships between the twenty items of both variables are positive, the most significant correlations between EP traits [35,37] and CT [1] occur, firstly, with the dimension called demand, specifically with the item "being enthusiastic", followed by the strengths dimension to which the four items with the most prevalent values belong ("developing positive self-esteem", "having self-confidence", "having balance" and "having self-control"). Enthusiasm is directly linked to two demand items, motivation and expectations, while self-esteem, self-confidence, balance and self-control are located in the strengths dimension. High self-esteem enhances academic performance [42,44] and, on the contrary, low self-esteem is detrimental to learning and even to one's health and well-being, as Asakereh and Yousofi [45] have shown. Our findings are also consistent with the study by Rodriguez [52] who, with a sample of first-year engineering undergraduates, concludes that there is significant correlation between CT and self-esteem (Spearman's Rho of 0.218 for $p=0.007<0.01$ ).

The multiple regression analysis evidences that EP has a positive and significant influence on CT. Specifically, the set of EP items explains $43.4 \%$ of the variance of the CT variable, with a confidence level of $99 \%$. Based on this, it is possible to conclude that the more the EP skills are acquired and developed, the greater the development of CT skills will be. These findings are consistent with the study by Asakereh and Yousofi [45], who report the existence of a significant relationship between $\mathrm{CT}$ and some elements of EP, such as self-esteem.

On the other hand, with regards to the sex of the participants, there are no significant differences, so that the influence of EP on CT continues to be positive. Although when the educational stage of the students (Primary or Secondary Education) intervenes, despite the fact that the variability of the adjustment increases-although not significantly - it is possible to affirm that students in Primary Education have higher CT scores than students in Secondary Education. This finding, although not worrisome, is disturbing, because in spite of EP and CT are acquired throughout life, it is in adolescence when the young person's perception and assessment of him/herself is crucial for both learning and psychosocial development (social skills, self-esteem, self-concept, etc.) [50]. There are several factors that could influence this fact. They include, on the one hand, the characteristics of adolescence, such as insecurity and fear of social evaluation, due to the biological changes that are accentuated between 12 and 18 years of age. On the other hand, it is possible that a second decisive factor is the lack of emotional education in families and schools. In the latter context, effective personality development, especially in Secondary Education, is significantly diminished due to lack of time, as the current educational curriculum is full of subjects with extensive and complex content [53]. In addition, these subjects are taught using traditional methodologies based on the teacher's exposition and the use of the textbook [54]. In contrast, in Primary Education, active methodologies are used that motivate student participation, the curriculum is more comprehensive, pupils are monitored more directly, there is a greater presence of the family in the school and emphasis is placed on the personal development of the student [55]. Consequently, it is urgent to design educational programmes that favour the emotional education and CT of Secondary Education students and that reinforce the comprehensive training of Primary Education students.

In sum, our study reveals that, in general, students who have EP traits such as enthusiasm and motivation, self-esteem, self-confidence, balance and self-control are more 
likely to have a higher level of CT. These capacities, taken together, are critical for learning and academic performance, as previously confirmed by [42-44]. Consequently, the findings suggest, in line with Tiruneh et al. [22], Radulović and Stančić [21], and Pilevarzadeh et al. [56], that EP is crucial for the development of CT.

$\mathrm{CT}$ is one of the key competencies for sustainability $[5-7,12,13,16,57,58]$, for living well and thriving in an uncertain and complex context and for developing other competencies [59]. Therefore, academics, educators, education policy-makers and all stakeholders are called upon to rethink ESD. Educational institutions have a responsibility to equip learners with skills and capabilities that enable them to transform themselves and society $[8,60]$. Consequently, the integration of specific competences linked to the development of EP and $\mathrm{CT}$ in the educational curriculum is crucial $[61,62]$. In a complementary way, it is suggested to design programmes to foster competences related to the development of EP and CT in adolescents using participatory strategies such as design thinking, service-learning, project-based learning, problem-based learning and simulation learning [63,64]. However, it should not be forgotten that learning EP-related skills has better results from an early age.

This study has several limitations. Firstly, it is necessary to stress the difficulty of measuring such a complex construct as EP. Therefore, despite the results of this research, it is still difficult to assert that CT is the cause or consequence of EP. Therefore, more in-depth studies are needed, with larger samples and in other contexts, to examine the relationships and the degree of influence between the two variables. This calls for the design and development of new research, both from the field of education and psychology. It would also be advisable to use mixed methodological approaches, as these, although they have been rarely used, have been shown to be effective in ESD research [6].

Author Contributions: Conceptualization, G.M.-M. and M.U.-S.; methodology, G.M.-M., M.U.-S. and D.G.-M.; software, D.G.-M. and S.B.-M.; validation, D.G.-M., M.U.-S. and S.B.-M.; formal analysis, G.M.-M.; investigation, G.M.-M., S.B.-M. and D.G.-M.; resources, M.U.-S.; data curation, S.B.-M.; writing-original draft preparation, G.M.-M. and D.G.-M.; writing-review and editing, D.G.-M.; visualization, S.B.-M.; supervision, G.M.-M. and M.U.-S. All authors have read and agreed to the published version of the manuscript.

Funding: This research was financed by the University of Alicante and the Generalitat Valenciana (Spain) in the framework of the project "Design and implementation of University Master's Programmes and Postgraduate Courses on Sustainable Development Goals: Education, Equality and Inclusion" (RES. CUD-10-2020).

Institutional Review Board Statement: Not applicable.

Informed Consent Statement: The data are not publicly available due to confidentiality agreements with the participants and IRB requirements. Any questions can be directed to the first author.

Data Availability Statement: Not applicable.

Acknowledgments: We are grateful for the participation in this research of the management staff, teachers, and students of primary and secondary schools in the province of Alicante (Spain).

Conflicts of Interest: The authors declare no conflict of interest.

\section{References}

1. UNESCO. Declaración de Aichi-Nagoya Sobre la Educación Para del Desarrollo Sostenible. Conferencia Mundial Aichi-Nagoya (Japón). 2014. Available online: https:/ / bit.ly/3Bh2MHO (accessed on 18 May 2021).

2. UNESCO. Education for Sustainable Development Goals: Learning Objectives. United Nations Educational, Scientific and Cultural Organization. 2017. Available online: https:/ / bit.ly/2Yyo8ln (accessed on 12 January 2021).

3. UNESCO-MGIEP. Textbooks for Sustainable Development: A Guide to Embedding; UNESCO-Mahatma Gandhi Institute of Education for Peace and Sustainable Development: New Delhi, India, 2017.

4. UNESCO. Issues and Trends in Education for Sustainable Development; United Nations Educational, Scientific and Cultural Organization: Paris, France, 2018.

5. Alismail, H.A.; Mcguire, P. 21st century standards and curriculum: Current research and practice. J. Educ. Pract. 2015, 6, 150-155.

6. Changwong, K.; Sukkamart, A.; Sisan, B. Critical thinking skill development: Analysis of a new learning management model for Thai high schools. J. Int. Stud. 2018, 11, 37-48. [CrossRef] [PubMed] 
7. Lamb, S.; Maire, Q.; Doecke, E. Key Skills for the 21st Century: An Evidence-Based Review; Cires: Melbourne, Australia, 2017.

8. Makrakis, V.; Kostoulas-Makrakis, N. Bridging the qualitative-quantitative divide: Experiences from conducting a mixed methods evaluation in the RUCAS programme. Eval. Program. Plann. 2016, 54, 144-151. [CrossRef]

9. Dewey, J. How We Think; D. C. Heath \& Co Publishers: Boston, MA, USA, 1910.

10. Galinsky, E. Mind in the Making: The Seven Essential Life Skills Every Child Needs; Harper Collins Publishing: New York, NY, USA, 2010.

11. Blanco-Lopez, A.; España-Ramos, E.; Franco-Mariscal, A.J. Estrategias didácticas para el desarrollo del pensamiento crítico en el aula de ciencias. Ápice. Rev. Educ. Cient. 2017, 1, 107-115. [CrossRef]

12. Ennis, R. Critical thinking: Reflection and perspective Part II. Inq. Crit. Think. Discip. 2011, 26, 5-19. [CrossRef]

13. Taimur, S.; Sattar, H. Education for sustainable development and critical thinking competency. In Quality Education. Encyclopedia of the UN Sustainable Development Goals; Leal Filho, W., Azul, A.M., Brandli, L., Özuyar, P.G., Wall, T., Eds.; Springer: Cham, Switzerland, 2020; pp. 238-248.

14. Aránguiz, P.; Palau-Salvador, G.; Belda, A.; Peris, J. Critical thinking using project-based learning: The case of the agroecological market at the "Universitat Politècnica de València". Sustainability 2020, 12, 3553. [CrossRef]

15. Sternberg, R.J.; Halpern, D.F. Critical Thinking in Psychology; Cambridge University Press: Cambridge, UK, 2020.

16. Atabaki, A.M.S.; Keshtiaray, N.; Yarmohammadian, M.H. Scrutiny of critical thinking concept. Int. Educ. Stud. 2015, 8, 93-102. [CrossRef]

17. Norman, M.; Chang, P.; Prieto, L. Stimulating critical thinking in U.S business students through the inclusion of international students. J. Bus. Diver. 2017, 17, 122-130.

18. Hove, G. Developing Critical Thinking Skills in the High School English Classroom. Master's Thesis, University of Wisconsin, Madison, WI, USA, May 2011.

19. Paul, R.; Elder, L. Critical thinking: Intellectual standards essential to reasoning well within every domain of human thought, Part 4. J. Develop. Educ. 2014, 37, 34-35.

20. Basri, H.; Purwanto; As'Ari, A.R.; Sisworo. Investigating critical thinking skill of junior high school in solving mathematical problem. Int. J. Instr. 2019, 12, 745-758. [CrossRef]

21. Radulović, L.; Stančić, M. What is needed to develop critical thinking in schools? CEPS J. 2017, 7, 9-25. [CrossRef]

22. Tiruneh, D.T.; De Cock, M.; Weldeslassie, A.G.; Elen, J.; Janssen, R. Measuring critical thinking in physics: Development and validation of a critical thinking test in electricity and magnetism. Int. J. Sci. Math. Educ. 2017, 15, 663-682. [CrossRef]

23. Piergiovanni, P.R. Creating a critical thinker. Coll. Teach. 2014, 62, 86-93. [CrossRef]

24. Savicki, V.; Price, M.V. Reflection in transformative learning: The challenge of measurement. J. Transform. Educ. 2021, 19, 366-382. [CrossRef]

25. Bennett, M.J. Paradigmatic assumptions and a developmental approach to intercultural learning. In Student Learning Abroad: What Our Students Are Learning, What They're Not, and What We Can Do about It; Vande Berg, M., Paige, R.M., Lou, K.H., Eds.; Stylus Publishing: Sterling, VA, USA, 2012; pp. 90-114.

26. Nakayama, M.; Kikuchi, S.; Yamamoto, H. Development of Critical Thinking Disposition during a Blended Learning Course. In European Conference on e-Learning; Academic Conferences International Limited: London, UK, 2020.

27. Martín del Buey, F.; Martín-Palacio, M.E. Competencias Personales y Sociales: Personalidad Eficaz. Material Inédito. Editado en Formato Digital sin Finalidad Venal; Universidad Autónoma de Madrid: Madrid, Spain, 2012.

28. Chiva-Bartoll, O.; Gil-Gómez, J.; Zorrilla-Silvestre, L. Improving the effective personality of pre-service teachers through service-learning: A physical education approach. Rev. Inv. Educ. 2019, 37, 327-343. [CrossRef]

29. Bandura, A.; Jeffery, R.W.; Gajdos, E. Generalizing change through participant modeling with self-directed mastery. Behav. Res. Ther. 1975, 13, 141-152. [CrossRef]

30. Gardner, H. Frames of Mind. In The Theory of Multiple Intelligences; Basic Books: New York, NY, USA, 1983.

31. Salovey, P.; Mayer, J.D. Emotional intelligence. Imagin. Cogn. Personal. 1990, 9, 185-211. [CrossRef]

32. Bar-On, R. The Bar-On model of emotional-social intelligence (Esi). Psicothema 2006, 18, 13-25.

33. Carpenter, B.N. Relational competence. In Advances in Personal Relationships; Perman, D., Jones, W.H., Eds.; Jessica Kingsley Publishers: London, UK, 1993.

34. Garmez, M.; Masten, A.S. The protective role of competence indicators in children at risk. In Life-Span Development Psychology: Perspectives on Stress and Coping; Cummings, M., Greene, A.L., Karraker, K.H., Eds.; LEA: Chicago, IL, USA, 1991.

35. Fueyo, E.; Martín, M.E.; Dapelo, B. Personalidad eficaz y rendimiento académico: Una aproximación integrada. Rev. Orient. Educ. 2010, 24, 57-70.

36. Chiva-Bartoll, O.; Pallarés-Piquer, M.; Gil-Gómez, J. Aprendizaje-servicio y mejora de la personalidad eficaz en futuros docentes de Educación Física. Rev. Comp. Educ. 2018, 29, 181-197. [CrossRef]

37. Martín del Buey, F.; Martín, M.E.; Dapelo, B.; Pizarro, J.P.; Di Giusto, C.; Castellanos, S.; Guerra, P.; Arnaiz, A. El constructo personalidad eficaz: Últimos avances. Rev. Orientac. Educ. 2015, 29, 51-68.

38. Castellanos, S.; Martín, M.E.; Dapelo, B. Cuestionario de personalidad eficaz en población adulta de 30 a 60 años. Rev. Orientac. Educ. 2012, 50, 15-30.

39. Martín del Buey, F.; Granados, P.; Martín, E.; Juárez, A.; García, A.; Álvarez, M. Desarrollo de la Personalidad Eficaz en Contextos Educativos. Marco Conceptual; Universidad de Oviedo: Oviedo, Spain, 2000. 
40. Hébert, A.; Hauf, P. Student learning through service learning: Effects on academic development, civic responsibility, interpersonal skills and practical skills. Act. Learn. High. Educ. 2015, 16, 37-49. [CrossRef]

41. Maruf, N.; Anjely, A.M. Utilizing cooperative integrated reading and composition (CIRC) with mobile learning to enhance students' reading comprehension. J. Bahasa Dan Sastra Inggris. 2020, 9, 10-19.

42. Bhagat, P. Relationship between self-esteem and academic achievement of secondary school students. Int. J. Innov. Res. Develop. 2016, 5, 211-216.

43. Clemes, H.; Bean, R. How to Teach Children Responsibility; Price Stern Sloan: Los Angeles, CA, USA, 1990.

44. González-Vázquez, B. ¿Cómo mejorar el aprendizaje? Influencia de la autoestima en el aprendizaje del estudiante universitario. Rev. Complut. Educ. 2019, 30, 781-795. [CrossRef]

45. Asakereh, A.; Yousofi, N. Reflective thinking, self-efficacy, self-esteem and academic achievement of Iranian EFL students in higher education: Is there a relationship? Int. J. Educ. Psychol. 2018, 7, 68-89. [CrossRef]

46. Hendriana, H.; Johanto, T.; Sumarmo, U. The role of problem-based learning to improve students' mathematical problem-solving ability and self confidence. J. Math. Educ. 2018, 9, 291-300. [CrossRef]

47. Lin, S.-H.; Wu, C.-H.; Chen, L.H. Unpacking the role of self-esteem in career uncertainty: A self-determination perspective. $J$. Posit. Psychol. 2015, 10, 231-239. [CrossRef]

48. Khavanin, A.; Sayyah, M.; Ghasemi, S.; Delirrooyfard, A. Correlations between critical thinking, self-esteem, educational status, and demographic information of medical students: A study from Southwestern Iran. Educ. Res. Med. Sci. 2021, 10, e116558. [CrossRef]

49. Olchowska-Kotala, A. Body esteem and self-esteem in middle-aged women. J Women Aging. 2017, 30, 417-427. [CrossRef]

50. Guerrero, R.; Martín, M.E.; Di Giusto, R.; De la Fuente, R.; González, C. La personalidad eficaz en adolescentes diagnosticados de trastorno por déficit de atención con hiperactividad (TDAH): Diferencias de género. Rev. Orientac. Educ. 2017, 31, 38-52.

51. Facione, P.; Facione, N. CCTDI: A Disposition Inventory. The California Academia Press: Milbrae, CA, USA, 1992.

52. Rodríguez, D. Pensamiento Crítico y Autoestima en Ingresantes de la Universidad Nacional de Ingeniería. Master's Thesis, Universidad César Vallejo, Lima, Peru, March 2016.

53. Consellería de Educación, Investigación, Cultura y Deporte. Decreto 51/2018, de 27 de abril, del Consell, por el que se Modifica el Decreto 87/2015, por el que Establece el Currículo y Desarrolla la Ordenación General de la Educación Secundaria Obligatoria y del Bachillerato en la Comunitat Valenciana. Diario Oficial de la Generalitat Valenciana 8284/30.04.2018. Available online: https:/ / bit.ly/3J3qRpB (accessed on 18 November 2021).

54. Travé, G.; Estepa, J.; Delval, J. Análisis de la fundamentación didáctica de los libros de texto de conocimiento del medio social y cultural. Educ. XXI 2017, 21, 319-338. [CrossRef]

55. Muntaner, J.J.; Pinya, C.; Mut, B. El impacto de las metodologías activas en los resultados académicos. Prof. Rev. Curríc. Form. Prof. 2020, 24, 96-114. [CrossRef]

56. Pilevarzadeh, M.; Mashayekhi, F.; Faramarzpoor, M.; Beigzade, M. Relationship between critical thinking disposition and self-esteem in bachelor nursing students. Biosci. Biotechnol. Res. Asia 2014, 11, 973-978. [CrossRef]

57. Howlett, C.; Ferreira, J.; Blomfield, J. Teaching sustainable development in higher education: Building critical, reflective thinkers through an interdisciplinary approach. Int. J. Sustain. High. Educ. 2016, 17, 305-321. [CrossRef]

58. UN. Transforming Our World: The 2030 Agenda for Sustainable Development. 2015. Available online: https://bit.ly/3uRQKSR (accessed on 28 April 2021).

59. Shava, G.N.; Chasara, T.; Hahlani, O.S. Sustainable Development Goal (SDG) 4 on quality in education, Current Issues in Zimbabwe Higher Education, Educating for the future. Int. J. Innov. Soc. Sci. 2021, V, 146-154.

60. Organisation for Economic Cooperation and Development. The Future of Education and Skills: Education 2030; Secretary-General: Paris, France, 2018.

61. Meng, K.H. Infusion of Critical Thinking across the English Language Curriculum: A Multiple Case Study of Primary School In-Service Expert Teachers in Singapore. Ph.D. Thesis, University of Western Australia, Perth, Australia, 2016.

62. Lombardi, L.; Mednick, F.J.; De Backer, F.; Lombaerts, K. Fostering critical thinking across the primary school's curriculum in the European Schools system. Educ. Sci. 2021, 11, 505. [CrossRef]

63. Straková, Z.; Cimermanová, I. Critical thinking development-a necessary step in higher education transformation towards sustainability. Sustainability 2018, 10, 3366. [CrossRef]

64. Urquidi-Martín, A.C.; Tamarit-Aznar, C.; Sánchez-García, J. Determinants of the eectiveness of using renewable resource management-based simulations in the development of critical thinking: An application of the experiential learning theory. Sustainability 2019, 11, 5469. [CrossRef] 